\title{
Tindak Perundungan di Sekolah Dasar dan Upaya Mengatasinya
}

\author{
Amiirohana Mayasari ${ }^{1}$, Syamsul $\mathrm{Hadi}^{2}$, Dedi Kuswandi ${ }^{3}$ \\ ${ }^{1}$ Pendidikan Dasar-Universitas Negeri Malang \\ ${ }^{2}$ Teknik Mesin-Universitas Negeri Malang \\ ${ }^{3}$ Teknologi Pembelajaran-Universitas Negeri Malang
}

\section{INFO ARTIKEL}

\section{Riwayat Artikel:}

Diterima: 08-02-2019

Disetujui: 20-03-2019

\section{Kata kunci:}

abuse; primary school: perundungan; sekolah dasar

\author{
Alamat Korespondensi: \\ Amiirohana Mayasari \\ Pendidikan Dasar \\ Universitas Negeri Malang \\ Jalan Semarang 5 Sumbersari Malang \\ E-mail: amiirohana@gmail.com
}

\section{ABSTRAK}

\begin{abstract}
The purpose: Find out actions, causes, and efforts to resolve bullying in SDN A and SDN B. Techniques for collecting data were observation, interviews, and document studies. The results: (1) the form of bullying is categorized into 3 types are physical, verbal and relational bullying, (2) causes of bullying: negative effects of the home environment, students feel powerful and feared in class, jealous of other students, and lack of empathy for students with special needs, (3) efforts: teachers approach the students involved in bullying, put up placards about prohibiting acts of bullying, and collaborate with Babinkamtibmas and the Social Service.
\end{abstract}

\begin{abstract}
Abstrak: Tujuan penelitian untuk mengetahui tindak, penyebab, dan upaya mengatasi perundungan di SDN A dan SDN B. Teknik pengumpulan data yaitu observasi, wawancara, dan studi dokumen. Hasil penelitian (1) bentuk perundungan dikategorikan menjadi tiga jenis perundungan, yaitu perundungan fisik, verbal, dan relasional, (2) penyebab perundungan pengaruh negatif dari lingkungan rumah, siswa merasa berkuasa dan ditakuti di kelas, siswa merasa iri dengan siswa lain, dan kurangnya empati terhadap siswa berkebutuhan khusus, (3) upaya: guru melakukan pendekatan kepada siswa yang terlibat perundungan, memasang plakat tentang larangan melakukan tindak perundungan, dan melakukan kerjasama dengan Babinkamtibmas dan Dinas Sosial untuk mengatasi tindak perundungan yang terjadi.
\end{abstract}

Pada masa sekolah dasar, siswa akan pertama kali berinteraksi dengan orang lain yang tidak pernah ditemui sebelumnya. Maka dari itu jenjang sekolah dasar merupakan bekal awal untuk dapat melanjutkan ke jenjang-jenjang selanjutnya hingga siswa mampu untuk berperan di lingkungan masyarakat. Sebagaimana telah tertuang pada Peraturan Menteri Pendidikan Nasional No. 23 Tahun 2006 yang menyatakan bahwa pendidikan dasar bertujuan meletakkan dasar kecerdasan, pengetahuan, kepribadian, akhlak mulia, serta keterampilan untuk hidup mandiri dan mengikuti pendidikan lebih lanjut. Jenjang sekolah dasar sangat penting bagi siswa jika dilihat dari penjelasan tersebut. Maka kenyamanan, keamanan, dan ketenangan siswa merupakan hal yang mutlak harus dirasakan siswa selama berada di sekolah.

Mengingat pentingnya kualitas proses belajar mengajar yang baik di sekolah, maka berbagai faktor yang dapat mengganggu proses belajar mengajar juga harus diperhatikan. Salah satu yang cukup sering menghambat proses belajar mengajar yaitu perundungan yang terjadi di sekolah. Perundungan merupakan salah satu bentuk kegiatan interaksi sosial yang dapat menimbulkan dampak negatif bagi pihak yang menerima perundungan. Hal tersebut sejalan dengan pendapat dari (Muliani \& Pereira, 2018) yang mengatakan bahwa perundungan merupakan penyalahgunaan kekuasaan yang berkelanjutan dalam suatu hubungan, melalui perilaku verbal, fisik, dan/atau sosial yang berulang yang menyebabkan kerugian fisik dan/atau psikologis. Sebagaimana yang dikemukakan oleh (Glew, Rivara, \& Feudtner, 2007) bahwa perundungan merupakan bentuk agresi di mana satu atau lebih anak-anak bermaksud untuk menyakiti atau mengganggu anak lain yang dianggap tidak mampu membela diri. Perundungan dalam bentuk apapun atau karena alasan apapun dapat memberi efek jangka panjang pada mereka yang terlibat, termasuk penonton atau siswa yang menyaksikan secara langsung tindak perundungan tersebut.

Perundungan yang terjadi mengakibatkan siswa mendapatkan kekerasan yang dilakukan oleh orang-orang di sekitarnya selama berada di sekolah. Menurut Lembaga Swadaya Masyarakat Plan International dan International Center for Research on Women sebesar 84 persen anak di Indonesia mengalami kekerasan di sekolah. Angka tersebut lebih tinggi dari tren di kawasan Asia yakni 70 persen (Qodar, 2015). Berdasarkan data yang dikemukakan oleh Menteri Sosial Khofifah Indar Parawansa, sebanyak 40 persen anak-anak di Indonesia meninggal karena bunuh diri akibat tidak kuat menahan tindakan perundungan yang 
dialami di sekolah (Syah, 2015). Beliau juga mengatakan bahwa lemahnya mental dan karakter pada anak-anak diduga kuat menjadi salah satu faktor besar yang mendorong mereka memilih bunuh diri dalam menghadapi tindakan perundungan. Pada harian Tempo (Hantoro \& Wasono, 2018) juga diberitakan bahwa terdapat tindakan perundungan yang dialami siswa SD di Kediri sehingga menyebabkan siswa tersebut mengalami infeksi otak. Peristiwa tersebut mengakibatkan terhambatnya pemerolehan pendidikan bagi siswa yang menjadi korban dikarenakan tidak dapat menghadiri kegiatan belajar mengajar di kelas. Selain itu, telah dilaporkan oleh (BBC Indonesia, 2017) terdapat kasus perundungan terhadap siswa SD di Jakarta yang menyebabkan siswa tersebut tidak berani masuk sekolah selama dua minggu. Perundungan tersebut terjadi karena siswa tersebut memiliki mata yang sipit dan berkulit putih. Siswa tersebut diejek oleh temannya dengan sebutan nama mantan gubernur Jakarta yang pada saat itu memiliki citra yang kurang baik di mata masyarakat. Tangan siswa tersebut juga pernah ditusuk dengan bolpoin oleh teman-temannya yang menjadi pelaku. Selama tahun 2011 hingga tahun 2017 Komisi Perlindungan Anak Indonesia (KPAI) telah menerima aduan sebanyak 26 ribu aduan mengenai kasus perundungan (Indrawan, 2017). Pada penelitian yang dilakukan oleh (Oliveira, de Menezes, Irffi, \& Oliveira, 2018) menyatakan bahwa perundungan memiliki dampak negatif pada kinerja siswa kelas VI dalam bidang matematika dan juga pada keterampilan emosional sosial yang dapat membantu siswa dalam menangani perundungan. Penelitian yang dilakukan oleh (Patras \& Sidiq, 2017) menyatakan bahwa perundungan dapat berdampak pada interaksi sosial yang menyebabkan korban perundungan sulit untuk berinteraksi dengan lingkungan karena selalu mengalami perundungan yang dilakukan oleh siswa lain. Perundungan yang terjadi juga dapat berpengaruh pada hasil akademis siswa sebagaimana yang dikemukakan oleh (Al-Raqqad, Al-Bourini, Al Talahin, \& Aranki, 2017) bahwa perilaku perundungan di sekolah dapat memengaruhi prestasi akademis siswa baik itu korban maupun pelaku.

Perundungan hingga saat ini masih menjadi masalah serius yang terjadi di lingkungan sekolah. Perundungan yang terjadi di sekolah perlu mendapatkan perhatian khusus dari warga sekolah antara lain yaitu kepala sekolah, guru, serta pegawai sekolah. Perundungan menjadi sangat penting untuk dibahas karena ini menyangkut kenyamanan siswa dalam menjalani kegiatan di sekolah berupa perolehan ilmu setiap harinya. Siswa biasanya berada di sekolah selama tujuh hingga delapan jam. Jika diakumulasikan selama enam hari, berarti siswa berada di sekolah selama kurang lebih 42 - 48 jam. Hal itu tentu akan memberikan tekanan besar atau kecemasan terus-menerus bagi siswa yang menjadi korban atau yang mengalami perundungan. Jika siswa merasa tertekan atau tidak nyaman selama berada di sekolah dikarenakan tindak perundungan yang diterimanya, maka pelajaran yang didapat di kelas akan sulit diterima dan hal tersebut dapat berdampak pada hasil belajar siswa selama di sekolah. Berdasarkan paparan yang dijelaskan diatas, peneliti ingin mengadakan penelitian tentang tindak perundungan di sekolah dasar dan upaya mengatasinya. Penelitian ini memfokuskan pada bentuk tindak perundungan, penyebab terjadinya tindak perundungan, dan juga upaya sekolah dalam mengatasi tindak perundungan.

\section{METODE}

Penelitian ini menggunakan pendekatan penelitian kualitatif deskriptif. Penelitian ini mendalami tentang tindak perundungan yang terjadi di SDN A dan SDN B Kota Malang serta upaya guru dan kepala sekolah dalam mengatasi perilaku perundungan tersebut. Pendekatan yang dilakukan dalam penelitian ini yaitu pendekatan studi kasus karena peneliti ingin mendalami suatu kasus tentang perundungan di sekolah dasar serta upaya mengatasinya. Penelitian ini juga termasuk penelitian studi kasus multisitus karena terdapat dua lokasi yang akan dijadikan latar penelitian untuk kemudian dianalisis persamaan maupun perbedaannya terkait dengan fokus penelitian. Peneliti mengeksplorasi tindak perundungan yang terjadi serta upaya guru dan kepala sekolah dalam mengatasi perilaku perundungan yang terjadi di SDN A dan SDN B Kota Malang. Peneliti juga mempelajari kondisi alami yang ada di SDN A dan SDN B Kota Malang selama kegiatan sekolah berlangsung.

Kehadiran peneliti pada penelitian ini sebagai instrumen utama dan pengumpul data yang mendalam dengan melakukan wawancara, observasi, serta studi dokumentasi. Menurut Moleong (2017) dalam penelitian kualitatif, peneliti sendiri yang merupakan alat pengumpul data utama. Peneliti berperan sebagai pengamat, perencana, pengumpulan data, penganalisis, penafsir, dan pelapor hasil penelitian. Peneliti datang langsung ke lokasi penelitian yaitu di SDN A dan SDN B Kota Malang untuk mengamati perilaku-perilaku perundungan yang terjadi selama kegiatan di sekolah berlangsung. Hal-hal yang akan dilakukan selama penelitian yaitu peneliti akan mengumpulkan data melalui wawancara, observasi, dan studi dokumen. Peneliti akan mewawancarai kepala sekolah dan guru terkait perundungan apa saja yang terjadi di sekolah serta upaya yang dilakukan dalam mengatasi perundungan di sekolah. Peneliti juga akan mewawancarai beberapa siswa untuk lebih mendalami tentang perundungan yang terjadi di sekolah. Kemudian peneliti melakukan observasi atau pengamatan kegiatan di sekolah mulai dari masuk hingga pulang sekolah. Selain itu, peneliti juga melakukan studi terhadap dokumen-dokumen yang berkaitan dengan perundungan di sekolah, seperti buku catatan kasus, foto-foto terkait kegiatan penanganan perundungan, serta tata tertib yang ada di sekolah.

Peneliti melakukan pengamatan melalui berbagai tahapan. Tahap pertama dimulai dengan melakukan observasi umum secara luas dengan menggambarkan secara umum kondisi lingkungan sekolah. Kemudian peneliti melakukan pengamatan tentang perilaku siswa secara umum selama disekolah mulai dari masuk sekolah hingga pulang sekolah. Selain itu, peneliti juga mengamati tindakan yang diberikan guru ketika siswa melakukan perundungan. Seluruh hasil observasi dicatat dan direkam sebagai pengamatan lapangan. Pada penelitian ini peneliti menggunakan tipe observasi non partisipan. Peneliti mengamati atau memperoleh data tanpa terlibat langsung dalam kegiatan yang ada di sekolah. Kehadiran peneliti juga diketahui statusnya oleh 
subjek penelitian yaitu sebagai pengamat. Pada pelaksanaan observasi, peneliti menggunakan bantuan aplikasi perekam gambar dari smartphone untuk memudahkan peneliti ketika menganalisis temuan yang didapat selama penelitian berlangsung.

Setelah data terkumpul, peneliti melakukan analisis data penelitian menggunakan analisis data yang telah dikembangkan oleh Cresswell (2018) yang tediri dari berbagai tahap antara lain yaitu organisasi data, pembacaan data, mendeskrripsikan data menjadi kode, mengklasifikasikan kode ke dalam tema, menafsirkan data, dan menyajikan data. Langkah selanjutnya setelah melakukan analisis, peneliti melakukan pengecekan keabsahan data. Penelitian dapat dikatakan abash apabila memenuhi empat kriteria, yaitu (1) kepercayaan, (2) keteralihan, (3) kebergantungan, dan (4) kepastian. Tahapan penelitian ini dilakukan dalam empat tahap, yaitu (1) tahap pra lapangan, (2) tahap pelaksanaan, (3) tahap analisis, dan (4) tahap penulisan laporan penelitian.

\section{HASIL}

\section{Pemahaman tentang Perundungan}

Pada saat penelitian berlangsung, guru maupun siswa di kedua situs ini tidak mengerti kata "perundungan". Guru belum pernah mendengar kata perundungan dan baru pertama kali mendegar kata tersebut ketika peneliti memberikan pertanyaan. Hal tersebut juga terjadi kepada siswa yang menyatakan bahwa mereka belum pernah mendengar kata tersebut. Kemudian peneliti menanyakan kepada guru maupun siswa dengan mengganti kata perundungan menjadi kata bullying. Ketika peneliti mengganti pertanyaan tentang pengertian bullying, guru maupun siswa dapat menjelaskan pemahaman mereka dengan lebih baik. Pengertian perundungan yang dijelaskan oleh guru di SDN A lebih mengarah kepada jenis perundungan itu sendiri. Selain itu guru tersebut juga memahami perundungan sebagai suatu tindak kekerasan. Pengertian tentang perundungan atau bullying yang dijelaskan oleh siswa lebih mengarah pada contoh tindak perundungan. Pengertian perundungan yang disampaikan oleh guru SDN B lebih mengacu kepada contoh dari bentuk perundungan. Pengertian perundungan yang dikemukakan siswa sama dengan yang dikemukakan oleh guru yang mengacu kepada bentuk perundungan.

\section{Bentuk Perundungan di Sekolah}

Perundungan yang terjadi di SDN A antara lain yaitu memukul, menendang meja siswa, mencubit, mengepakngepakkan hasduk ke arah siswa lain, menarik hijab siswa perempuan, mencekik siswa lain, mencolek, merusakkan barang milik siswa lain, melemparkan alat tulis milik siswa lain, menyeret, menelanjangi siswa lain, melakukan labelling (memanggil dengan nama sebutan), nyandak (memanggil siswa dengan plesetan nama orangtua), mengejek atau menghina, menggosipkan siswa lain, menertawakan, melotot, mengancam, mengucilkan, serta menarget atau meminta uang kepada siswa lain secara paksa. Perundungan yang terjadi di SDN B antara lain yaitu memukul, mendorong bangku siswa lain, mengambil barang milik siswa lain, menarik hijab siswa perempuan, melemparkan barang ke arah siswa lain, memainkan rambut siswa lain, menggelitik secara berlebihan, melakukan labelling (memanggil dengan nama sebutan), menggoda, nyandak (memanngil siswa dengan plesetan nama orangtua), mengejek atau menghina, mengucilkan, menertawakan, mengancam, serta menarget atau meminta uang kepada siswa lain secara paksa.

\section{Penyebab Tindak Perundungan di Sekolah}

Berdasarkan penelitian yang telah dilakukan terdapat penyebab perundungan yang hampir sama antara SDN A dan SDN B Kota Malang. Penyebab terjadinya tindak perundungan antara lain yaitu pengaruh dari lingkungan rumah. Siswa melakukan tindak perundungan khususnya jenis perundungan verbal seperti nyandak (memanggil siswa dengan menyebutkan nama orang tua siswa yang dipanggil) karena meniru apa yang ada di lingkungan rumah mereka. Berdasarkan wawancara dengan siswa ditemukan bahwa beberapa orang di sekitar lingkungan rumah siswa melakukan tindak perundungan seperti nyandak yang kemudian ditiru oleh siswa.

Penyebab lain dari terjadinya tindak perundungan yaitu adanya siswa yang merasa berkuasa di kelas juga menjadi salah satu penyebab terjadinya tindak perundungan. Siswa yang merasa berkuasa di kelas menyuruh siswa lain untuk menuruti permintaannya ketika di sekolah seperti menyuruh untuk membelikan makanan di kantin. Siswa tersebut merasa berkuasa di kelas sehingga dia dapat berbuat semena-mena terhadap yang lainnya seperti melakukan tindak perundungan

Siswa yang iri kepada siswa lain juga merupakan salah satu penyebab tindak perundungan. Selama penelitian berlangsung di SDN B Kota Malang, peneliti mengamati ada seorang siswa perempuan yang selalu sendirian ketika istirahat. Siswa tersebut sendirian karena tidak ada siswa yang ingin berteman dengannya. Hal tersebut terjadi karena menurut siswasiswa yang lain siswa tersebut sombong dan tidak dimarahi oleh guru ketika melakukan gerakan yang salah pada saat latihan untuk mengibarkan bendera. Selain itu siswa yang selalu sendirian ini menurut siswa-siswa yang lain selalu mencari perhatian kepada guru. Hal tersebut juga dibenarkan oleh guru kelas dengan mengatakan bahwa siswa yang menjadi objek pengucilan oleh teman-temannya memang memiliki kepribadian yang sombong karena kelebihannya dalam membacakan puisi dan sudah memenangkan beberapa kejuaraan lomba membaca puisi. 
Penyebab lain dari adanya tindak perundungan di kedua sekolah tersebut yaitu ketika ada siswa yang memiliki kekurangan dalam bentuk fisik tubuhnya. Sebagaimana yang terjadi di SDN A Kota Malang pada kelas IV dan V. Seorang siswa laki-laki memiliki bentuk tubuh yang kecil dan pendek sehingga teman-temannya melakukan labelling (memanggil menggunakan sebutan) kepada siswa tersebut dengan sebutan 'bocil'. Selain itu, ada siswa yang dihina bentuk hidungnya oleh teman sekelasnya dengan mengatakan "D iku pesek" yang kemudian diikuti dengan tertawa yang keras dan seperti mengejek. Hal yang sama juga terjadi di SDN B Kota Malang. Ketika ada siswa yang memiliki bau badan, siswa-siswa yang lain menghina dengan mengatakan "kelekmu kecut". Kurangnya empati yang dimiliki siswa juga bisa menjadi penyebab tindak perundungan. Sebagaimana yang terlihat di SDN B Kota Malang terdapat siswa berkebutuhan khusus yang selalu sendirian ketika istirahat. Tidak ada siswa lain yang ingin berteman dengan siswa berkebutuhan khusus tersebut karena menurut siswa lain anak yang berkebutuhan khusus merupakan siswa yang aneh.

\section{Upaya Mengatasi Perundungan di Sekolah}

SDN A Kota Malang mempunyai berbagai upaya dalam mengurangi tindak perundungan yang terjadi. Upaya yang dilakukan di sekolah bermula dari upaya yang dilakukan secara mandiri oleh guru. Ketika terjadi tindak perundungan di kelas guru akan berusaha untuk menanganinya secara mandiri terlebih dahulu. Guru berusaha memberikan pendekatan kepada siswa baik yang menjadi pelaku perundungan maupun korban perundungan. Guru meminta siswa untuk menceritakan secara jujur tindak perundungan yang telah terjadi. Guru berbicara baik-baik kepada siswa yang melakukan tindak perundungan maupun siswa yang menjadi objek perundungan. Guru menasehati siswa yang melakukan tindak perundungan agar tidak mengulangi perbuatannya lagi. Guru memberikan nasehat kepada siswa tentang bagaimana bersikap yang baik dalam berteman. Jika melalui pendekatan perilaku siswa tidak berubah maka guru akan melakukan upaya selanjutnya seperti memindahkan siswa pelaku perundungan ke kelas lain dengan harapan agar siswa tersebut merasa jera dan tidak mengulangi perbuatannya lagi. Upaya tersebut hampir sama dengan upaya yang dilakukan oleh SDN B Kota Malang. Tahapan pertama yang dilakukan SDN B yaitu guru memanggil siswa yang melakukan tindak perundungan dan siswa yang menjadi objek perundungan. Jika kasus perundungan yang dihadapi terasa berat bagi guru kelas untuk mengatasinya maka kasus tersebut dialihkan kepada guru bagian kesiswaan dan kepala sekolah. Tujuan guru kelas yang menjadi tahapan pertama mengatasi perundungan yaitu karena guru kelas yang paling mengerti sifat dan karakteristik siswanya. Guru kelas melakukan pendekatan kepada siswa dengan cara menuntun siswa untuk menceritakan peristiwa yang sebenarnya terjadi.

Upaya lain yang dilakukan oleh kedua situs ini yaitu dengan memasang plakat tentang larangan melakukan tindak perundungan pada setiap kelas. Pada SDN A plakat tersebut ada di setiap depan kelas dan terdapat pula di kantin serta di sekitar ruang guru. Plakat tersebut dipasang bertujuan agar siswa senantiasa melihat plakat tersebut di sekolah dan membantu mencegah siswa berbuat sesuatu yang merugikan salah satunya tindak perundungan. Sekolah sudah mengupayakan memasang plakat tersebut di depan setiap kelas, tetapi dalam pengimplementasiannya masih belum maksimal. Pada SDN B plakat tersebut terdapat di setiap kelas dan juga beberapa titik di dalam sekolah. Pada plakat tersebut dijelaskan bahwa perundungan merupakan salah satu tindak kekerasan di sekolah yang menjadi fokus penanganan tindak kekerasan di sekolah. Tindak perundungan yang terjadi di sekolah tersebut dapat dilaporkan atau diadukan kepada guru kelas, kesiswaan, kepala sekolah, babinkamtibmas, babinsa, dan polsek sebagaimana yang dijelaskan pada plakat tersebut. Tujuan dari adanya plakat tersebut yaitu untuk memberikan edukasi kepada siswa bahwa poin-poin yang tertera pada plakat tersebut seperti pembulian, penganiayaan, pemerasan, pelecehan, penghinaan, dan tindak kekerasan yang lain merupakan contoh dari tindak kekerasan yang bisa terjadi di sekolah. Penulisan subjek pengaduan pada plakat tersebut bertujuan agar siswa memahami kepada siapa siswa harus melapor atau mengadu jika terjadi tindak perundungan.

Kerjasama dengan pihak luar sekolah juga menjadi upaya bagi kedua situs ini untuk mengatasi tindak perundungan. Kedua situs ini bekerjasama dengan Babinkamtibmas yang berada dekat dengan sekolah. Perwakilan dari babinkamtibmas secara rutin datang ke sekolah untuk memberikan penyuluhan-penyuluhan bagi siswa salah satunya terkait tindak kekerasan yang termasuk di dalamnya tindak perundungan. Namun, pada SDN B Kota Malang tidak hanya bekerjasama dengan Babinkamtibmas akan tetapi juga bekerjasama dengan Dinas Sosial Provinsi Jawa Timur. Kerja sama yang dilakukan SDN B Kota Malang dengan Dinas Sosial Provinsi Jawa Timur berbentuk kegiatan rehabilitasi bagi anak yang dianggap mengalami hambatan sosial dalam bergaul. Siswa direhabilitasi selama kurang lebih satu bulan dengan didampingi oleh guru. Selama melaksanakan rehabilitasi, siswa diberikan beberapa bentuk bimbingan dari Dinas Sosial Provinsi Jawa Timur antara lain yaitu (1) bimbingan fisik, (2) bimbingan sosial, (3) bimbingan mental, (4) bimbingan keterampilan, (5) bimbingan akademik, dan (6) tes psikologi. Bimbingan fisik sendiri terdiri dari kegiatan olahraga, pengenalan lingkungan, dan kerumahtanggaan. Bimbingan sosial terdiri dari kegiatan Out Bond, dinamika kelompok, metode belajar, simulasi sikap sosial, diskusi kelompok, dan rekreasi. Bimbingan mental terdiri dari bimbingan keagamaan, etika/budi pekerti, dan kedisiplinan. Bimbingan keterampilan terdiri dari pramuka, dan kesenian (tari, angklung, rebana, qiro'ah). Bimbungan akademik terdiri dari kegiatan intrakurikuler/pelajaran sekolah sesuai kalender pendidikan. Tes psikologi terdiri dari tes kecerdasan umum dan tes kepribadian. 


\section{PEMBAHASAN \\ Pemahaman tentang Perundungan}

Guru dan siswa di kedua sekolah tersebut tidak pernah mendengar kata "perundungan". Namun, mayoritas warga di kedua sekolah tersebut mengetahui padanan kata dari perundungan yaitu bullying. Guru di SDN A dan SDN B Kota Malang sudah cukup memahami pengertian bullying atau perundungan. Secara ringkas, guru menyatakan bahwa perundungan merupakan tindak kekerasan yang terdiri dari kekerasan fisik dan kekerasan perkataan yang dilakukan berulang-ulang sehingga dapat menyakiti orang lain. Hal tersebut sesuai dengan pernyataan yang dijelaskan oleh (American Psychological Association, n.d.) bahwa perundungan merupakan sebuah bentuk perilaku agresif di mana seseorang dengan sengaja dan berulang kali menyebabkan orang lain cedera atau tidak nyaman. Hal tersebut hampir sama dengan yang dikemukakan oleh (Glew et al., 2007) bahwa perundungan merupakan bentuk agresi di mana satu atau lebih anak-anak bermaksud untuk menyakiti atau mengganggu anak lain yang dianggap tidak mampu membela diri. Sementara itu, pemahaman siswa tentang bullying atau perundungan lebih mengarah pada bentuk perundungan seperti memukul, menghina, menyiksa, pengeroyokan, pelecehan, dan juga penganiayaan. Pemahaman yang telah dipaparkan oleh guru maupun siswa di SDN A dan SDN B Kota Malang sudah sesuai dengan pengertian yang dikemukakan oleh (Muliani \& Pereira, 2018) bahwa perundungan merupakan penyalahgunaan kekuasaan yang berkelanjutan dalam suatu hubungan, melalui tindakan verbal, fisik, dan/atau sosial yang berulang yang menyebabkan kerugian fisik dan/atau psikologis.

\section{Bentuk Perundungan di Sekolah}

Bentuk perundungan yang terjadi di kedua sekolah tersebut, seperti memukul, menendang meja siswa, mencubit, menampar dengan hasduk, menarik hijab siswa perempuan, mencekik siswa lain, mencolek, merusakkan barang milik siswa lain, melemparkan alat tulis milik siswa lain, menyeret, menelanjangi siswa lain, mendorong bangku siswa lain, mengambil barang milik siswa lain, memainkan rambut siswa lain, dan menggelitik secara berlebihan termasuk ke dalam jenis perundungan fisik. Hal tersebut sesuai dengan teori yang dikemukakan oleh (Rosen, DeOrnellas, \& Scott, 2017) bahwa perundungan yang mengacu pada penggunaan kekuatan oleh pelaku perundungan termasuk ke dalam perundungan fisik.

Bentuk perundungan lain yang terjadi di kedua sekolah ini yaitu melakukan labelling (memanggil dengan nama sebutan), nyandak (memanggil siswa dengan plesetan nama orangtua), mengejek atau menghina termasuk ke dalam perundungan verbal. Hal tersebut dikarenakan perundungan yang terjadi menggunakan media verbal atau melalui ucapan. Sebagaimana menurut (Dupper, 2013) bahwa perundungan verbal merupakan perundungan yang dilontarkan secara verbal atau ucapan, seperti memanggil nama yang menyakitkan, mengejek, mengancam, dan menggoda secara jahat.

Perundungan lainnya yang terjadi di SDN A dan SDN B, antara lain menggosipkan siswa lain, menertawakan, melotot, mengancam, mengucilkan, serta menarget atau meminta uang kepada siswa lain secara paksa. Bentuk-bentuk perundungan tersebut termasuk ke dalam jenis perundungan relasional. Sebagaimana yang dikemukakan oleh Coloroso (2007) bahwa perilaku yang terjadi dalam perundungan relasional biasanya, seperti pandangan yang agresif, lirikan mata, helaan napas, cibiran, tawa yang mengejek, dan bahasa tubuh yang kasar.

\section{Penyebab Perundungan di Sekolah}

Penyebab terjadinya perundungan di kedua situs ini disebabkan oleh berbagai hal yang berkaitan dengan pelaku maupun korban perundungan. Pertama, perundungan di sekolah disebabkan karena adanya pengaruh negatif dari lingkungan rumah maupun lingkungan pertemanan siswa yang kemudian ditiru dan dibawa ke lingkungan sekolah. Perundungan verbal yang terjadi di lingkungan rumah kemudian ditiru dan dibawa oleh siswa ke dalam lingkungan sekolah sehingga siswa tersebut juga melakukan perundungan verbal terhadap siswa lain. Sebagaimana (Cook, Williams, Guerra, Kim, \& Sadek, 2010) bahwa pelaku perundungan mendapatkan faktor negatif dari komunitasnya serta cenderung dipengaruhi secara negatif oleh temantemannya.

Penyebab selanjutnya dari terjadinya tindak perundungan di kedua situs tersebut yaitu ketika ada siswa yang merasa berkuasa dan juga merasa ditakuti oleh siswa lain. Ketika ada seorang siswa yang merasa takut dengan siswa lain, maka secara tidak langsung siswa yang takut tersebut memberikan penghargaan kepada siswa yang ditakuti dan juga secara tidak langsung memberikan persetujuan bahwa siswa yang ditakuti tersebut memang berkuasa di kelas. Sebagaimana penyebab tindak perundungan yang telah dikemukakan oleh (American Society for the Positive Care of Children, 2018) bahwa ketika beberapa siswa di kelas merasa takut kepada salah satu siswa, maka secara tidak langsung siswa yang ditakuti oleh teman-temannya ini merasa dihargai dan secara tidak sengaja memperoleh perhatian dari siswa lain di kelas. Menurut (Jan \& Husain, 2015) salah satu penyebab perundungan di sekolah yaitu ketika ada siswa yang merasa paling kuat. Penyebab lainnya dari tindak perundungan yaitu ketika ada siswa yang iri terhadap siswa yang memiliki kelebihan. Selain itu, (Jan \& Husain, 2015) juga menyebutkan bahwa penyebab adanya tindak perundungan yaitu karena adanya kecemburuan atau iri hati terhadap kelebihan yang dimiliki oleh siswa lain. 
Kurangnya empati yang dimiliki siswa juga bisa menjadi penyebab tindak perundungan. Sebagaimana yang terjadi di SDN B Kota Malang ditemukan bahwa siswa tidak ada yang mau bermain dengan siswa yang berkebutuhan khusus. (American Society for the Positive Care of Children, 2018) mengemukakan bahwa seorang anak dapat melakukan perundungan karena ada aspek kepribadian anak lain yang tidak mereka pahami dalam hal ini kepribadian siswa berkebutuhan khusus.

\section{Upaya Mengatasi Tindak Perundungan di Sekolah}

SDN A dan SDN B Kota Malang menyadari bahwa terjadi tindak perundungan di sekolah. Salah satu upaya yang telah dilakukan oleh SDN A dan SDN B Kota Malang untuk mengatasi tindak perundungan yang terjadi yaitu dengan cara melakukan pendekatan kepada siswa yang melakukan tindak perundungan maupun siswa yang menjadi objek tindak perundungan. Guru juga memberikan nasehat kepada siswa berupa pengalaman tindak perundungan yang telah terjadi agar bisa diambil pelajaran oleh siswa. Guru juga membuat kesepakatan terkait tindak perundungan dengan siswa pada awal masuk sekolah. Sebagaimana yang dikemukakan oleh (Kyriakides \& Creemers, 2013) bahwa salah satu upaya yang dapat dilakukan guru untuk mencegah terjadinya tindak perundungan yaitu dengan cara membuat perjanjian dengan siswa terkait tindak perundungan di awal semester. Hal tersebut didukung oleh (Spiegler, 2017) yang menyatakan bahwa strategi yang dapat dilakukan guru untuk mencegah perundungan yaitu mengubah tindak perundungan menjadi momen yang bisa diajarkan dengan mendiskusikan apa yang terjadi dan bagaimana seseorang bertindak sebagai pelaku perundungan. Hal tersebut juga ditambahkan oleh (Espelage, Polanin, \& Low, 2014) yang menyatakan bahwa menegakkan norma atau aturan lingkungan sekolah yang aman akan menciptakan iklim sekolah yang positif dapat mengurangi perilaku bermasalah seperti perundungan. Sebagaiman yang ditambahkan oleh (Tucker \& Maunder, 2015) menyatakan bahwa perundungan dapat diatasi dengan cara mengajarkan siswa keterampilan dalam bergaul atau berteman.

Upaya lain yang dilakukan kedua sekolah tersebut yaitu dengan mengampanyekan secara tertulis larangan melakukan tindakan kekerasan yang juga termasuk perundungan melalui pemasangan plakat di setiap area kelas. Pada SDN A Kota Malang plakat yang terpasang diberikan judul "Budayakan Malu". Pada plakat tersebut terdapat salah satu poin bentuk perundungan seperti berkelahi, berkata jorok, dan juga mengganggu teman. Plakat yang terpasang pada SDN B Kota Malang berjudul "Kawal Sekolah Aman! Jangan Diamkan Aksi Kekerasan”. Pada plakat tersebut terdapat pembulian atau perundungan yang menjadi salah satu fokus tindakan yang dilarang di sekolah. Plakat dari SDN B Kota Malang juga dilengkapi dengan keterangan kepada siapa siswa harus mengadu ketika terjadi tindak perundungan. (Dixon \& Smith, 2011) menjelaskan bahwa salah satu upaya mengatasi perundungan yaitu dengan membuat kebijakan sekolah terkait dengan perundungan.

Kerjasama dengan pihak luar sekolah juga dilakukan oleh kedua sekolah tersebut. SDN A dan SDN B Kota Malang bekerjasama dengan Babinkamtibmas yang berada di lingkungan dekat sekolah untuk mengatasi perilaku yang melanggar nilai dan norma yang ada salah satunya tindak perundungan. Namun, pada SDN B Kota Malang tidak hanya melakukan kerjasama dengan Babinkamtibmas, tetapi sekolah tersebut juga bekerjasama dengan Dinas Sosial Provinsi Jawa Timur untuk memberikan pembelajaran tentang keterampilan sosial. Siswa yang dikatakan bermasalah termasuk siswa yang melakukan tindak perundungan akan direhabilitasi oleh Dinas Sosial. Selama masa rehabilitasi tersebut, siswa akan dilatih untuk mengembangkan keterampilan sosial maupun emosionalnya. (Goldweber, Waasdorp, \& Bradshaw, 2013) mengemukakan bahwa perlu mengajarkan kepada siswa tentang keterampilan sosial untuk mengatasi tindak perundungan. Selain itu, (Morrow, Hooker, \& Cate, 2015) juga menambahkan bahwa kolaborasi yang dilakukan antara sekolah dan konsultan profesional dapat memperkuat program anti perundungan yang sudah ada sebagai bentuk pencegahan tindak perundungan di sekolah.

\section{SIMPULAN}

Berdasarkan penelitian yang telah dilakukan, bentuk perundungan yang terdapat di kelas IV dan V SDN A dan SDN B kota Malang dapat dikategorikan ke dalam tiga jenis perundungan yaitu perundungan fisik, perundungan verbal, dan juga perundungan relasional. Perundungan di kedua sekolah tersebut rata-rata dilakukan pada saat istirahat atau pun ketika tidak ada guru di sekitar siswa. Siswa melakukan tindak perundungan ketika sedang tidak berada dalam pengawasan guru. Perundungan terjadi setiap hari meskipun bentuk perundungan yang dilakukan merupakan bentuk perundungan ringan seperti nyandak, melakukan labelling, serta mengejek atau menghina. Namun, dari bentuk perundungan ringan tersebut ada beberapa kasus yang pada akhirnya menimbulkan perkelahian.

Tindak perundungan yang terjadi di SDN A dan SDN B Kota Malang terjadi karena disebabkan oleh beberapa hal. Pertama, adanya pengaruh negatif dari lingkungan rumah tempat tinggal siswa. Penyebab lain dari terjadinya tindak perundungan yaitu karena adanya siswa yang merasa berkuasa dan ditakuti oleh siswa lainnya di kelas. Tindak perundungan yang terjadi juga disebabkan karena rasa iri yang dimiliki siswa terhadap siswa lain yang memiliki kelebihan dalam kegiatan non akademik. Bentuk fisik yang dimiliki siswa juga menjadi penyebab terjadinya tindak perundungan. Penyebab lain dari adanya tindak perundungan yaitu ketika ada siswa yang memiliki kekurangan, seperti siswa berkebutuhan khusus

Upaya yang dilakukan oleh SDN A dan SDN B Kota Malang salah satunya yaitu melalui pendekatan yang diberikan oleh guru kelas kepada siswa yang menjadi pelaku dan juga korban tindak perundungan. Kedua sekolah tersebut juga secara memasang plakat di setiap kelas yang salah satu poinnya berisikan larangan melakukan tindak perundungan. Selain upaya yang dilakukan sekolah secara mandiri, sekolah juga membangun kerjasama dengan pihak luar, yaitu dengan Babinkamtibmas yang berada di sekitar SDN A dan SDN B Kota Malang. Perbedaan dari upaya yang dilakukan yaitu terlihat dari kerjasama yang 
dilakukan SDN B Kota Malang. Sekolah tersebut selain bekerjasama dengan Babinkamtibmas juga bekerja sama dengan Dinas Sosial Provinsi Jawa Timur dengan cara merehabilitasi siswa yang bermasalah salah satunya siswa yang melakukan tindak perundungan.

Perlu diadakan penyuluhan dan pelatihan secara berkala bagi guru sekolah dasar terkait dengan tindak perundungan mulai dari pemahaman tentang perundungan, penyebab tindak perundungan, karakteristik pelaku maupun korban perundungan di sekolah, dan juga cara mengatasi atau mengurangi tindak perundungan serta upaya pencegahannya. Sekolah perlu bekerjasama dengan pakar untuk membuat program anti perundungan yang permanen dan konsisten dijalankan di sekolah. Memberikan sanksi yang tepat bagi siswa yang melakukan tindak perundungan dan mengajarkan kepada siswa untuk selalu melaporkan segala bentuk tindak perundungan. Selain itu, pembentukan karakter perlu dilaksanakan secara rutin. Sekolah perlu mengadakan workshop tentang perundungan dengan mengundang orangtua siswa agar orangtua juga memahami segala hal yang berkaitan dengan perundungan dan bersama dengan sekolah ikut mengawasi tanda-tanda adanya tindak perundungan.

Sekolah juga perlu memberikan pelajaran tentang pendidikan seks yang sesuai dengan usia anak sekolah dasar karena terdapat kasus perundungan yang mengarah kepada pelecehan. Guru perlu mengajarkan kepada siswa untuk selalu melaporkan tindak perundungan yang terjadi. Selain itu, siswa juga perlu diajarkan untuk peduli kepada siswa yang menjadi objek perundungan dan juga siswa perlu diajarkan tentang bagaimana harus bertindak ketika tindak perundungan sedang terjadi. Guru juga dapat membagikan kuesioner atau angket tentang permasalahan yang sedang siswa hadapi, melalui kuisioner tersebut, guru dapat melakukan pendekatan yang tepat kepada siswa.

\section{DAFTAR RUJUKAN}

Al-Raqqad, H. K., Al-Bourini, E. S., Al Talahin, F. M., \& Aranki, R. M. E. (2017). The Impact of School Bullying On Students' Academic Achievement from Teachers Point of View. International Education Studies, 10(6), 44. https://doi.org/10.5539/ies.v10n6p44

American Society for the Positive Care of Children. (2018). Causes of Bullying. Retrieved from https://americanspcc.org/wpcontent/uploads/2013/04/Bullying-Causes-of-Courtesy-of-nobullying.pdf

BBC Indonesia. (2017). Anak SD yang dibully dengan kata-kata “dasar Ahok”, ekses Pilkada DKI Jakarta. Retrieved from https://www.bbc.com/indonesia/trensosial-41819789

Coloroso, B. 2007. Stop Bullying! Memutus Rantai Kekerasan Anak dari Prasekolah Hingga SMU. Edisi Pertama. Diterjemahkan oleh: Santi Indra Astuti. Jakarta: PT. Serambi Ilmu Semesta.

Cook, C. R., Williams, K. R., Guerra, N. G., Kim, T. E., \& Sadek, S. (2010). Predictors of Bullying and Victimization in Childhood and Adolescence: A Meta-Analytic Investigation. School Psychology Quarterly, 25(2), 65-83. https://doi.org/10.1037/a0020149

Cresswell, J. W. 2018. Penelitian Kualitatif \& Desain Riset (Memilih di antara Lima Pendekatan). Diterjemahkan oleh Ahmad Lintang Lazuardi. Yogyakarta: Pustaka Pelajar.

Dixon, R., \& Smith, P. K. (2011). Rethinking School Bullying: Towards An Integrated Model. Cambridge: Cambridge University Press.

Dupper, D. R. (2013). School Bullying (New Perspective on a Growing Problem). New York: Oxford University Press.

Espelage, D. L., Polanin, J. R., \& Low, S. K. (2014). Teacher and Staff Perceptions of School Environment as Predictors of Student Aggression, Victimization, and Willingness to Intervene in Bullying Situations. School Psychology Quarterly, 29(3), 287-305. https://doi.org/10.1037/spq0000072

Glew, G., Rivara, F., \& Feudtner, C. (2007). Bullying: Children Hurting Children. Pediatrics in Review, 21(6), 183-190. https://doi.org/10.1542/pir.21-6-183

Goldweber, A., Waasdorp, T. E., \& Bradshaw, C. P. (2013). Examining the Link Between Forms of Bullying Behaviors and Perceptions of Safety and Belonging Among Secondary School Students. Journal of School Psychology, 51(4), 469-485. https://doi.org/10.1016/j.jsp.2013.04.004

Hantoro, J., \& Wasono, T. H. (2018). Siswa SD di Kediri Jadi Korban Bullying, Alami Infeksi Otak. Retrieved from https://nasional.tempo.co/read/1055133/siswa-sd-di-kediri-jadi-korban-bullying-alami-infeksi-otak

Indrawan, A. F. (2017). KPAI Terima Aduan 26 Ribu Kasus Bully Selama 2011-2017. Retrieved from https://news.detik.com/berita/d-3670079/kpai-terima-aduan-26-ribu-kasus-bully-selama-2011-2017

Jan, A., \& Husain, S. (2015). Bullying in Elementary Schools: Its Causes and Effects on Students. Journal of Education and Practice, 6(19), 43-57.

Kyriakides, L., \& Creemers, B. P. M. (2013). Characteristics of effective schools in facing and reducing bullying. School Psychology International, 34(3), 348-368. https://doi.org/10.1177/0143034312467127

Moleong, L. J. (2017). Metodologi Penelitian Kualitatif. Bandung: PT. Remaja Rosdakarya.

Morrow, M. T., Hooker, S. D., \& Cate, R. L. (2015). Consultation in Bullying Prevention: An Elementary School Case Study. School Community Journal, 25(2), 85-111. http://search.ebscohost.com/login.aspx?direct=true \&db=eric\&AN=EJ1085662\&lang=es\&scope=site

Muliani, H., \& Pereira, R. (2018). Why Children Bully. PT. Grasindo. 
Oliveira, F. R., de Menezes, T. A., Irffi, G., \& Oliveira, G. R. (2018). Bullying Effect on Student's Performance. Economia, 19(1), 57-73. https://doi.org/10.1016/j.econ.2017.10.001

Patras, Y. E., \& Sidiq, F. (2017). Dampak Bullying bagi Kalangan Siswa Sekolah Dasar. Jurnal Pedagogika dan Dinamika Pendidikan, 6(1). https://ejournal.unpatti.ac.id/ppr_iteminfo_lnk.php?id=1572

Pemerintah Indonesia. (2006). Peraturan Menteri Pendidikan Nasional No. 23 Tahun 2006 tentang Standar Kompetensi Lulusan untuk Satuan Pendidikan Dasar dan Pendidikan Menengah. Lembaran RI Tahun 2006 No. 23. Jakarta: Sekretariat Negara

Qodar, N. (2015). Survei ICRW: 84\% Anak Indonesia Alami Kekerasan di Sekolah. https://www.liputan6.com/news/read/2191106/survei-icrw-84-anak-indonesia-alami-kekerasan-di-sekolah

Rosen, L. H., DeOrnellas, K., \& Scott, S. R. (2017). Bullying in School (L. H. Rosen, K. DeOrnellas, \& S. R. Scott, Eds.). https://doi.org/10.1057/978-1-137-59298-9

Spiegler, J. (2017). Empowering Students to Curb Bullying. https://www.edutopia.org/article/empowering-students-curbbullying

Syah, M. H. (2015). Mensos: Bunuh Diri Anak Indonesia 40 Persen karena Bullying. https://www.liputan6.com/news/read/2361551/mensos-bunuh-diri-anak-indonesia-40-persen-karena-bullying

Tucker, E., \& Maunder, R. (2015). Helping Children to get along: Teachers' Strategies for Dealing with Bullying in Primary schools. Educational Studies, 41(4), 466-470. https://doi.org/10.1080/03055698.2015.1043980 